\title{
Atividades com Comunicação \& Educação Ano XI - n. 3
}

Ruth Ribas Itacarambi

Doutora pela Faculdade de Educação da USP.

Educadora e pesquisadora do CAEM - Centro de Aperfeiçoamento do Ensino da Matemática do IME-USP. Professora da FOC - Faculdade Osvaldo Cruz. Membro da Equipe SiteEducacional.

E-mail: ruthri@uol.com.br

O educador já não é o que educa, mas o que, enquanto educa, é educado, em diálogo com o educando que, ao ser educado, também educa. ${ }^{1}$

A concepção de educação varia de uma cultura para outra. A reflexão sobre as concepções de educação nas diferentes organizações socioculturais é um dos propósitos das atividades desta edição. O sistema educativo tem por missão preparar cada um à participação num projeto de sociedade. Nas sociedades complexas atuais, a participação em projetos comuns ultrapassa a ordem do político, no sentido estrito. Há, pois, que se pensar a educação na preparação de cada pessoa para a participação, discutindo os seus direitos e deveres, mas também desenvolvendo suas competências sociais e o trabalho coletivo.

Por outro lado, a educação trata da informação e de modo geral pode-se dizer que, onde quer que uma informação seja transmitida de um emissor para um receptor, tem-se um ato de comunicação. Não há comunicação sem informação, mas também não há transmissão de informação sem um meio pelo qual a informação transite; assim como não há ligação entre emissor e receptor se estes não compartilharem um código comum ou, segundo Freire, um diálogo e a importância da presença do educador como meio.

Neste contexto vamos analisar, na primeira atividade, o papel da educação em diferentes espaços culturais locais. O propósito é discutir o conceito de educação que varia de uma cultura para outra, mostrando que na maioria das sociedades industrializadas a educação está ligada às idéias de ensino, nas quais os pais, depois a escola, organizada pela sociedade, e seus professores ensinam. O ensino passa a ser um tipo de comunicação em que o saber é

1. FREIRE, Paulo. Pedagogia do oprimido. Rio de Janeiro: Paz e Terra, 2005. p. $78-79$. 
comunicação \& educação • Ano XI • Número 3 • set/dez 2006

como um líquido. Pais, professores e os mais velhos ou cultos têm o saber e tentam derramar o saber adulto para dentro da cabeça das crianças. As referências para a abordagem inicial do tema vão desde o artigo nacional Comunicação e educação para a cidadania em uma cooperativa de assentamento do $M S T$ - que trata de outra forma de ver a educação e a comunicação, na qual a primeira não é sinônimo de ensino, mas diz respeito à complexidade do processo de formação humana, que tem nas práticas sociais o principal meio de aprendizado -, passa pelo artigo internacional A educação entre os Parintintim: temos muito a aprender com eles - em que se discute a educação presente na sociedade contemporânea e faz-se um paralelo com a educação de uma nação indígena do Brasil, os Parintintim; neste caso, o processo comunicativo é o da aprendizagem e a problemática não é uma questão de ensino, mas de como aprender -, e chegam até o artigo da seção Experiência, Desenvolvendo atividades colaborativas na escola - o qual fala da influência das tecnologias no cotidiano escolar e da busca de novas metodologias de utilização desses aparatos no universo da escola no sentido de torná-los significativos no processo ensino-aprendizado.

A segunda atividade continua a discussão da educação nos diferentes espaços culturais e traz para reflexão a questão da recepção e da alfabetização audiovisual na comunicação. Os artigos selecionados são Arte também é educação - um depoimento do trabalho com educação e arte na formação de cidadãos, e o envolvimento com públicos heterogêneos; propõe a linguagem corporal como meio de comunicação -, o internacional Os meios de comunicação de massa na era da internet - que aborda a preocupação com as culturas locais e a contribuição da televisão na construção da cultura nacional - e o da seção Crítica, Da comunicação à educação: a importância dos estudos de recepção - em que é feita uma análise do livro Comunicação e recepção, sobre o lugar e a ação do sujeito receptor no processo comunicacional.

Trazer uma contribuição para a prática da educação como ação libertadora é a intenção da terceira atividade. Conforme aponta Freire, "a educação libertadora, problematizadora, já não pode ser o ato de depositar, ou de narrar, ou de transferir, ou de transmitir conhecimentos e valores aos educandos"'

As bases para a proposta de práticas libertadoras são a entrevista Informação, um bem público, direito do cidadão!, que mostra a importância de se abrirem espaços públicos de debate sobre o direito à informação; o artigo nacional Televisão digital interativa: expectativas de uso cultural e educativo, uma reflexão sobre as possibilidades abertas com a instituição da televisão digital no País; e o Serviço oferecido nesta edição, O Museu da Lingua Portuguesa, na Estação da Luz, o novo museu da cidade de São Paulo e que, segundo seus organizadores, pretende surpreender as pessoas e fazer com que descubram aspectos da língua que falam, lêem e escrevem, bem com da cultura do País. 


\section{PRIMEIRA ATIVIDADE}

\section{Educação em diferentes espaços culturais locais}

A atividade pretende discutir a educação como comunicação em diferentes espaços culturais locais. Estamos denominando espaços locais tanto a forma de organização do processo de ensino-aprendizado dos Parintintim como a do MST, pois ambos pertencem a um espaço global, que é a cultura industrializada da sociedade contemporânea, e de certa forma sofrem sua influência. Esta questão é abordada no artigo A educação entre os Parintintim: temos muito a aprender com eles, de Waud H. Kracke.

O tema para a sala deve se pautar por uma visão ampla da educação e dos meios de comunicação.

A atividade está organizada utilizando-se os seguintes procedimentos:

1) Colocar algumas perguntas iniciais para os educandos: o que é educação para você? Qual é o papel da escola na educação? Qual é o papel da família na educação?

2) Fazer a síntese dos depoimentos com as informações. Dedicar atenção especial para a visão que o jovem tem da educação - tão em evidência nos discursos políticos - e os limites da escola e da família.

3) Em seguida, ler o artigo de Kracke. Convidar o educando a realizar, em grupo, um quadro comparativo entre a sua educação, escola e família, com a educação do jovem indígena Parintintim.

4) Solicitar que, em grupo, os alunos desenvolvam uma pesquisa entre os adultos da comunidade sobre as questões do primeiro item, acrescentando uma pergunta sobre os recursos didáticos utilizados.

5) Organizar, na sala de aula, uma tabela geral dos resultados da pesquisa e comparar com o quadro do terceiro item, discutindo as características comuns e as diferenças. Dar especial atenção, nesse momento, aos recursos didáticos utilizados em sala de aula ou aos espaços locais de educação.

Lembrar que o respeito aos direitos e aos conhecimentos adquiridos dos primeiros grupos culturais do País é, também, uma das mais eficazes formas de conservar e promover a rica diversidade biológica e cultural de uma nação.

A continuidade do estudo sobre o significado da educação em diferentes espaços culturais locais apóia-se no artigo Desenvolvendo atividades colaborativas na escola, de Caroline L. Guedes e Hugo Rosenthal, que demonstra a experiência com o ensino-aprendizado, permitindo aos alunos de escolas em diferentes estados a construção dos conhecimentos a partir de informações procedentes de diversos saberes disciplinares e uma troca afetiva e social; o aspecto a realçar é que esses alunos estavam em espaços físicos diferentes e o meio de comunicação utilizado foi a internet, ou seja, um recurso das chamadas novas tecnologias -, e no artigo nacional Comunicação e educação para a cidadania em uma cooperativa 
comunicação \& educação • Ano XI • Número 3 • set/dez 2006

de assentamento do MST, de Luzia M. Y. Deliberador e Ana Carolina R. Vieira, no qual se explica a concepção de educação do MST e de comunicação da comunidade, com base em uma pesquisa denominada participante.

A seleção sugere algumas questões para reflexão na sala de aula:

1) Solicitar aos alunos a leitura dos artigos para que identifiquem o que é uma ação colaborativa e uma ação cooperativa, e como cada artigo apresenta a sua utilização na educação.

2) Discutir com os educandos o significado das ações (colaborativa e cooperativa) e pedir que reconheçam essas ações nas propostas dos trabalhos de grupo em sala de aula.

3) Pedir que, em grupo, discutam e em seguida registrem suas idéias sobre o significado de: respeito ao ser humano, respeito ao meio ambiente, trabalho coletivo e participação igualitária.

4) Sugerir que retomem os artigos citados e pesquisem neles os relatos dos autores sobre os temas dos itens anteriores e comparem a opinião do grupo com a encontrada nos textos.

5) Sintetizar as considerações em sala de aula, destacando as formas de organização para desenvolver o trabalho de ensino-aprendizado nos diferentes espaços educativos locais.

\section{SEGUNDA ATIVIDADE}

\section{Arte e educação, comunicação, direito do cidadão}

A questão sempre presente para o educador é como acontecem a aprendizagem e a busca de novas metodologias para o cotidiano escolar. $\mathrm{O}$ artigo $\mathrm{Os}$ meios de comunicação de massa na era da internet, de Guillermo Orozco Gómez, professor da Universidade de Guadalajara, mostra que é preciso analisar a escola da atualidade no cenário do advento das novas tecnologias da comunicação e dos conflitos que provoca. O artigo da seção Crítica, Da comunicação à educação: a importância dos estudos de recepção, de Maria Aparecida Baccega e Margaret de Oliveira Guimarães, aborda a questão: que pretende o professor senão se comunicar? O tema da atividade deve se pautar na educação como prática da liberdade, na medida em que os alunos, ao refletirem sobre si e sobre o mundo, vão ampliando a percepção de como estão inseridos nele.

A atividade está organizada na seguinte seqüência didática:

1) Propor aos alunos a leitura individual do artigo de Orozco e apresentar algumas perguntas norteadoras: qual é a contribuição da televisão na sua educação escolar? qual o papel da televisão, do cinema e da internet para a geração de uma cultura nacional? Qual é o meio de comunicação mais popular no seu bairro e/ou escola?

2) Discutir o artigo em sala de aula e as respostas dos alunos às perguntas. 
3) Solicitar que, em grupo, façam a síntese de suas opiniões.

4) Sugerir que com a síntese do grupo cada aluno faça uma redação, cujo tema pode ser uma das perguntas anteriores ou, de forma mais ampla, o tema: "A contribuição dos meios de comunicação para a formação cultural do jovem".

5) Propor a leitura das diferentes redações, nos grupos, de preferência sem citar o autor.

6) Selecionar as redações que, segundo os grupos, abordaram o tema de forma pertinente, atendendo às demandas deles enquanto jovens.

7) Fazer uma revisão, se necessário, e publicar no mural, no jornal da escola e/ou no site da escola.

Nesta atividade, o artigo Da comunicação à educação: a importância dos estudos de recepção é sugerido como apoio ao professor. Objetiva provocar a reflexão sobre como ele vê o seu processo comunicativo em sala de aula e mostrar que comunicação não é só a veiculada pelos suportes tecnológicos. Como dizem as autoras: "Comunicação é interação entre sujeitos que, na maioria das vezes, utiliza o meio mais democrático de todos os suportes: o aparelho fonador".

No artigo Arte também é educação, o depoimento do premiado coreógrafo Ivaldo Bertazzo sobre seu trabalho com educação e arte na formação de cidadãos apresenta a linguagem corporal como meio de comunicação e a experiência de trabalhar com públicos heterogêneos. Sugerimos que os dois artigos citados sejam utilizados nas reuniões pedagógicas de planejamento da escola e/ou de grupos comunitários.

Os artigos propiciam algumas questões para a reflexão dos professores e/ou líderes comunitários sobre o seu trabalho:

1) Solicitar a leitura crítica dos dois artigos, grifando as idéias do texto que considerem mais significativas.

2) Fazer um painel das idéias grifadas e registrar uma síntese no quadro ou em outro espaço de comunicação.

3) Pedir que as pessoas presentes, utilizando a linguagem corporal, identifiquem: como é o seu público?

4) Propor que a partir da identificação do público façam uma reflexão sobre: como o jovem de hoje aprende? Como trabalhar com a heterogeneidade? Como trabalhar com a inclusão? (Observação: nesta proposta, pode-se utilizar outras linguagens e não apenas a escrita ou a oral.)

5) Sintetizar no painel os resultados da reflexão individual e discutir coletivamente as ações didáticas de interferência de cada um no seu público-alvo.

O depoimento de Ivaldo Bertazzo traz algumas ações que ele foi construindo com o seu público - cidadãos das mais variadas formações e moradores de comunidades de baixa renda de dois centros urbanos -, que podem ser iluminadoras de ações didáticas. O livro Comunicação e recepção, citado anteriormente, pode ser considerado como outra fonte de pesquisa de ações. 
comunicação \& educação • Ano XI • Número 3 • set/dez 2006

\section{TERCEIRA ATIVIDADE}

\section{Informação, direito do cidadão}

Os pontos que podem ser abordados nos artigos selecionados para essa atividade dizem respeito aos meios presentes na sociedade contemporânea que permitem favorecer a visão da educação como ação libertadora - a partir de práticas em sala de aula - ao educador preocupado com a problematização da realidade, a fim de que ajude o processo de ensino-aprendizado. No artigo Informação, um bem público, direito do cidadão!, em entrevista a Roseli Fígaro, Eugênio Bucci, presidente da Radiobrás, levanta a questão da informação como um direito; e no artigo nacional Televisão digital interativa: expectativas de uso cultural e educativo, Marcelo Sacrini traz novas formas de se ter acesso à informação.

A atividade que propomos dirige-se a um público bem específico: os educadores e comunicadores, pois está direcionada a práticas problematizadoras.

1) Ler a entrevista de Bucci e sintetizar as ações apresentadas pelo entrevistado, tais como: a Agência Brasil, a criação da Associação de Rádios Públicas e da TV Brasil.

2) Fazer um levantamento do número de concessões de rádios e canais de televisão nos dois últimos anos e quais foram os critérios adotados nesse processo.

3) Comparar os resultados dos dois itens acima e discutir o significado de: "o cidadão comum tem o direito à informação, à notícia, e ele deve se orientar com certa autonomia” (p. 396).

4) Solicitar que escolham duas emissoras de rádio e/ou televisão, uma pública e outra comercial, e gravem alguns momentos da programação do chamado horário nobre, das 20 às 22 horas.

5) Analisar a programação das emissoras escolhidas.

A leitura do artigo de Sacrini dá continuidade a essa reflexão, agora centrada no uso da televisão digital nos processos educativos e seu aproveitamento enquanto espaço para veiculação de programas culturais interativos, com a migração das emissoras ao novo sistema e sua possível potencialidade como repositório de programas para acesso on-demand.

Após a leitura do artigo de Sacrini, retomar as programações escolhidas no item quatro e discutir quais efetivamente têm potencial cultural e educativo, e como problematizar os conteúdos veiculados como práticas em suas salas de aula.

O tema da seção Serviço, O Museu da Lingua Portuguesa, na Estação da Luz, de Consuelo Ivo, apresenta o novo museu da cidade de São Paulo. O visitante pode observar e utilizar a língua das mais diversas maneiras, comunicando-se com criatividade e humor. $\mathrm{O}$ museu tem recursos de multimídia e projeto de oficinas de capacitação de professores. Os museus em geral têm sido os espaços culturais e educativos da humanidade. Tal leitura oferece uma visão desse museu em particular e mostra ao educador a importância para a 


\section{Atividades com Comunicação \& Educação • Ruth Ribas Itacarambi}

educação, também, dos demais museus existentes em suas localidades, como espaços culturais, fazendo um contraponto com as outras mídias da sociedade contemporânea.

Resumo: As três atividades com os artigos desta edição da revista têm como propósito a reflexão sobre as concepções de educação nas diferentes organizações socioculturais; a questão da recepção e da alfabetização audiovisual na comunicação; o trabalho com educação e arte na formação de cidadãos e a linguagem corporal como meio de comunicação; a preocupação com as culturas locais e a contribuição da televisão na construção da cultura nacional; e a ajuda para a prática da educação como ação libertadora, abordando o papel da informação pública e as possibilidades de interação midiática.

Palavras-chave: educação e espaços culturais locais, arte e educação, comunicação, informação e direito do cidadão, ensino-aprendizado.
Abstract: The purpose of the three activities presented aims at reflecting on the conception of education in different socio-cultural organizations, the matter of reception and audiovisual literacy in communication, the work with education and art in the formation of citizens and body language as media, the concern with local cultures and television contribution to national culture building, the contribution to the practice of education as a liberating action, approaching the role of public information and the possibilities of media interaction.

Keywords: education and local cultural spaces, art and education, communication, information and citizens' rights, teachinglearning process. 